\title{
Factors Related To Hygiene Behavior Of Food Sanitation On Karak Crackers Manufacturing Workers In Home Industry In Karanganyar District, Indonesia
}

\author{
Authors: \\ Dyah Suryani1 Dhimas \\ Iqbal Maulana ${ }^{2}$, Suyitno $^{3}$ \\ First Author \\ dyah.suryani@ikm.uad.ac.id, \\ Faculty of Public Health, \\ Universitas Ahmad Dahlan, \\ Indonesia $^{1}$ \\ Second Author E-mail: \\ dhimasiqbal120499@gmail.c \\ om, Faculty of Public Health, \\ Universitas Ahmad Dahlan, \\ Indonesia ${ }^{2}$ \\ Third Author E-mail: \\ senopalawija@gmail.com, \\ MPHM, ASEAN Institute for \\ Health Development, Mahidol \\ University, Thailand ${ }^{3}$ \\ Corresponding Author: \\ Dyah Suryani \\ E-Mail: \\ dyah.suryani@ikm.uad.ac.id
}

\section{DOI :10.24903/kujkm.v7i2.1031.}

Received : November 2021

Accepted : November 2021

Published : December 2021

P-ISSN: 2477-1880 E-ISSN: 2502-6623 Kesmas Uwigama : Jurnal Kesehatan Masyarakat

\section{Abstract}

Background: Foodborne disease is food poisoning that can cause illness or death as a result of consuming contaminated food. Food contamination can occur due to biological, physical, and chemical contamination, if food hygiene and sanitation behavior is not good in its application, especially for food handlers.

Objectives:The purpose of this study was to determine the factors related to hygiene behavior of food sanitation in workers making karak crackers in the home industry of Kerjo Sub-district, Karanganyar Regency, Central Java Province, Indonesia.

Research Method: This study was using the quantitative analytical observational method with a cross-sectional design. The number of samples was 38 workers making Karak crackers with a total sampling technique. Data analysis used fisher's exact $\mathrm{Cl}$ 95\% $(\alpha=0.05)$.

Findings: This study found that the majority of the age range was 17-45 with education level (81.6\%), knowledge level (65.8\%), negative attitude (52.6\%), and poor food sanitation hygiene behavior (68.4\%). The results of Fisher's exact test showed that the variables of age ( $p$-value $=0.147)$ and education level ( $p$-value $=0.176)$ were not significantly related to hygiene behavior of food sanitation. While the level of knowledge $(p$-value $=0.30)$ and attitudes $(p$-value $=0.49)$ have a significant relationship.

Conclusion: In sum, the level of knowledge and attitudes of the respondents are the factors that influence the hygiene behavior of food sanitation. Therefore, it is necessary to conduct training on food hygiene and sanitation practices for food handlers.

Keywords: hygiene behavior; food sanitation; home industry

\section{Abstrak}

Latar Belakang: Penyakit bawaan makanan adalah keracunan makanan yang dapat menyebabkan penyakit atau kematian akibat mengkonsumsi makanan yang terkontaminasi. Pencemaran makanan dapat terjadi karena cemaran biologis, fisik, dan kimia, jika perilaku higiene dan sanitasi makanan dalam penerapannya kurang baik, terutama bagi penjamah makanan.

Tujuan: Tujuan penelitian ini adalah untuk mengetahui faktor-faktor yang berhubungan dengan perilaku higiene sanitasi makanan pada pekerja pembuatan kerupuk karak di industri rumah tangga Kecamatan Kerjo Kabupaten Karanganyar Provinsi Jawa Tengah Indonesia.

Metode Penelitian: Penelitian ini menggunakan metode observasional analitik kuantitatif dengan desain potong lintang. Jumlah sampel adalah 38 pekerja pembuatan kerupuk karak dengan teknik total sampling. Analisis data menggunakan Fisher's Exact $\mathrm{Cl} 95 \%(\alpha=0,05)$.

Temuan: Penelitian ini menemukan bahwa mayoritas rentang usia adalah 17-45 tahun dengan tingkat pendidikan $(81,6 \%)$, tingkat pengetahuan $(65,8 \%)$, sikap negatif $(52,6 \%)$, dan perilaku higiene sanitasi makanan yang buruk $(68,4 \%)$. Hasil uji eksak Fisher menunjukkan bahwa variabel umur ( $p$-value $=0,147)$ dan tingkat pendidikan ( $p$-value $=0,176$ ) tidak berhubungan signifikan dengan perilaku higiene sanitasi makanan. Sedangkan tingkat pengetahuan $(p$-value $=0,30)$ dan sikap $(p$-value $=0,49)$ memiliki hubungan yang signifikan. 
Kesimpulan: Secara ringkas, tingkat pengetahuan dan sikap responden merupakan faktor-faktor yang mempengaruhi perilaku higiene sanitasi makanan. Oleh karena itu, perlu diadakan pelatihan tentang praktik higiene dan sanitasi makanan bagi penjamah.

Kata kunci: perilaku hygiene; sanitasi makanan; industri rumah tangga

\section{Pendahuluan}

Foodborne disease disebabkan akibat mengkonsumsi makanan atau minuman yang telah tercemar mikroorganisme, mikroba pathogen maupun zat kimia yang beracun dan tidak terolah dengan baik atau masih belum memenuhi standar dan menyebabkan penyakit pada manusia (Li et al., 2020; Siyam \& Cahyati, 2018). Kejadian Foodborne disease mengakibatkan angka kematian sebanyak 420.000 jiwa dan angka kesakitan 600 juta orang yang disebabkan oleh agen berbahaya seperti virus, bakteri, parasit dan bahan kimia (Pires \& Devleesschauwer, 2021; Todd, 2020).

Pada tahun 2017 terjadi kasus KLB keracunan makanan di Indonesia dengan angka Attack Rate (AR) sebesar 38,65\% dan Case Fatality Rate (CFR) sebesar 0,15\%. Salah satu penyebabnya diakibatkan oleh pangan olahan rumah tangga sebanyak 4 kasus dengan jumlah korban sebanyak 183 orang (BPOM, 2017). Sumber pangan terjadinya kejadian luar biasa keracunan akibat makanan disumbangkan oleh makanan olahan rumah tangga, jasa boga, jajanan, pangan olahan pabrikan (terdaftar MD/ML), home industry tidak terdaftar, dan restoran secara nasional akibat makanan jajanan juga terbilang cukup tinggi yaitu sebesar $16 \%$ dan sebesar 2\% akibat makanan olahan industri rumah tangga pangan tidak terdaftar (BPOM, 2019).
Menurut Teori Lawrence Green, faktor predisposisi adalah salah satu determinan yang mempengaruhi seseorang dalam berperilaku (usia, Pendidikan, pengetahuan, dan sikap) (Notoatmodjo, 2011). Selain itu, terdapat 6 prinsip hygiene sanitasi makanan antara lain pemilihan bahan baku, penyimpanan bahan baku, pengolahan bahan baku, penyimpanan bahan makanan, pengolahan makanan, penyimpanan makanan dan pengangkutan hingga penyajian makanan (Hatta \& Marahena, 2018). Prinsip hygiene sanitasi makanan yang diterapkan sangat berpengaruh terhadap kualitas pangan yang dihasilkan terhadap Kesehatan konsumen (Marriott et al., 2018). Salah satu makanan yang dihasilkan seperti makanan jajanan seperti kerupuk buatan home industry (Supitra et al., 2018).

Provinsi Jawa tengah merupakan provinsi yang terdapat cukup banyak kegiatan home industry makanan. Kerupuk karak merupakan olahan produk lokal yang sedang berkembang pada masa kini yang dimanfaatkan masyarakat sebagai sumber penghasilan masyarakat di Provinsi Jawa Tengah khususnya di Kecamatan Kerjo, Kabupaten Karanganyar. Bahan dasar pembuatan kerupuk karak terdiri dari beras, bleng (bahan kimia semacam boraks), dan tambahan bumbu seperti bawang putih, bawang merah dan garam. Berdasarkan hasil studi pendahuluan di Kecamatan Kerjo 
terdapat 18 home industry dengan jumlah total pekerja sebanyak 38 pekerja.

Hasil wawancara terkait hygiene sanitasi makanan yang dilakukan pada tanggal 11-12 juni 2021 pada pekerja dari beberapa tempat home industry didapatkan kriteria umur sekitar 25-60 tahun dengan mayoritas pendidikan pekerja rendah. Hasil observasi lapangan pada 3 (tiga) tempat home industry kerupuk karak terdapatkan 6 (enam) pekerja tidak menggunakan baju, sarung tangan, masker, penutup rambut dan mencuci tangan tanpa menggunakan sabun. Kemudian beberapa peralatan yang digunakan terlihat tidak layak seperti, pisau dan spatula berkarat, wadah adonan terbuat dari kayu terlihat kotor, terdapat pekerja yang merokok dan menggunakan perhiasan pada saat proses pembuatan kerupuk karak. Sehingga penelitian ini bertujuan untuk mengetahui faktor-faktor yang berhubungan dengan perilaku hygiene sanitasi makanan pada pekerja pembuatan kerupuk karak di home industry, Kecamatan Kerjo, Kabupaten Karanganyar.

\section{Metode Penelitian}

Metode penelitian yang digunakan dalam penelitian ini adalah metode kuantitatif, yaitu jenis penelitian observasional analitik, yang bertujuan untuk mengetahui hubungan antara sebab-sebab dalam fakta- fakta sosial terukur. Desain penelitian yang digunakan adalah metode analitik observasional menggunakan rancangan cross sectional. Cross sectional merupakan suatu penelitian yang digunakan untuk mencari hubungan antara variabel bebas (yang mempengaruhi) dengan variabel terikat (yang dipengaruhi) yang variabelnya diukur dalam satu kali pada satu waktu.

Pengambilan sampel dilakukan menggunakan Teknik total sampling. Sampel penelitian adalah pekerja pembuatan kerupuk karak di home industry Kecamatan Kerjo sebanyak 38 pekerja.

Pengumpulan data menggunakan kuesioner untuk variabel bebas dan lembar observasi pada variabel terikat. Kuesioner yang digunakan untuk pengambilan data dibuat berdasarkan modifikasi dari penelitian Septiyani (2021) yang disesuaikan dengan (Peraturan Menteri Kesehatan RI Nomor 1096/MENKES/PER/VI/2011) tentang Higiene Sanitasi Jasaboga terkait dengan prinsip pengolahan makanan.

Sedangkan kuesioner untuk pengetahuan dan sikap sebelumnya di uji validitas dan reliabilitas terlebih dahulu dengan nilai alpha cronbach pengetahuan sebesar 0,745 dan sikap sebesar 0,769. data dianalisis dengan menggunakan uji alternatif fisher's exact untuk variabel umur, tingkat pendidikan dan tingkat pengetahuan karena terdapat nilai expected count kurang dari 5 (tidak memenuhi syarat chi square). Sedangkan pada variabel sikap dianalisis menggunakan uji chi square.

\section{Hasil Penelitian}

Berdasarkan table 1 didapatkan bahwa pekerja pembuatan kerupuk karak bahwa lebih banyak pada kategori umur dewasa yaitu sebesar 24 orang $(63,2 \%)$. Sedangkan tingkat pendidikan lebih besar pada kategori rendah yaitu sebanyak 31 orang $(81,6 \%)$, tingkat pengetahuan lebih besar pada kategori tinggi yaitu sebesar 25 orang $(65,8 \%)$. Sikap pekerja diketahui lebih besar pada kategori negative sebesar 20 orang $(52,6 \%)$. Perilaku hygiene sanitasi makanan (HSM) tidak baik yaitu sebesar 26 $(68,4 \%)$.

Tabel 1. Distribusi frekuensi responden

\begin{tabular}{lcc}
\hline Variabel Penelitian & Frekuensi (n) & Presentase (\%) \\
Variabel & & \\
\hline Jenis Kelamin & 15 & $39,5 \%$ \\
Laki-Laki & 23 & $60,5 \%$ \\
Perempuan & & \\
Umur & 14 & $36,8 \%$ \\
Lansia & 24 & $63,2 \%$ \\
Dewasa & & \\
Tingkat Pendidikan & 31 & $81,6 \%$ \\
Rendah & 7 & $18,4 \%$ \\
Tinggi & &
\end{tabular}




\begin{tabular}{lcc}
$\begin{array}{l}\text { Tingkat } \\
\text { Pengetahuan }\end{array}$ & \\
$\quad$ Rendah & 31 & $81,6 \%$ \\
Tinggi & 7 & $18,4 \%$ \\
Sikap & & \\
$\quad$ Negatif & 20 & $52,6 \%$ \\
Positif & 18 & $47,4 \%$ \\
Perilaku HSM & \\
$\quad$ Tidak Baik & 26 & $68,4 \%$ \\
$\quad$ Baik & 12 & $31,6 \%$ \\
\hline HSM: Hygiene Sanitasi Makanan &
\end{tabular}

*HSM: Hygiene Sanitasi Makanan

Hasil uji fisher's Exact pada table 2 yang telah dilakukan, didapatkan tidak ada hubungan umur ( $\mathrm{p}$ value $=0,147)$ dan tingkat pendidikan ( $\mathrm{p}$ value $=0,147$ ) dengan perilaku hygiene sanitasi makanan. Sedangkan berdasarkan hasil uji fisher's exact yang telah dilakukan bahwa ada hubungan tingkat pengetahuan ( $\mathrm{p}$ value $=$ 0,030 ) dengan perilaku hygiene sanitasi makanan. Adapun berdasarkan uji chi square bahwa ada hubungan antara sikap (p value $=0,049$ ) dengan perilaku hygiene sanitasi makanan.

Tabel 2. Analisis bivariat variable bebas dan variable terikat

\begin{tabular}{|c|c|c|c|c|c|c|}
\hline \multirow[t]{3}{*}{ Variabel } & \multicolumn{4}{|c|}{ Perilaku HSM } & \multirow{3}{*}{$\begin{array}{l}\text { RP \& CI } \\
(95 \%)\end{array}$} & \multirow{3}{*}{$\begin{array}{l}P \text { - } \\
\text { value }\end{array}$} \\
\hline & & Baik & Bail & & & \\
\hline & $\mathrm{n}$ & $\%$ & & $\%$ & & \\
\hline \multicolumn{7}{|l|}{ Umur } \\
\hline Lansia & 12 & $85,7 \%$ & 2 & $14,3 \%$ & \multirow[t]{3}{*}{ - } & \multirow[t]{3}{*}{0,147} \\
\hline Dewasa & 14 & $58,3 \%$ & 10 & $41,7 \%$ & & \\
\hline \multirow{2}{*}{\multicolumn{7}{|c|}{ Pendidikan }} \\
\hline & & & & & & \\
\hline Rendah & 23 & $74,2 \%$ & 8 & $25,8 \%$ & \multirow[t]{3}{*}{ - } & \multirow[t]{2}{*}{0,176} \\
\hline Tinggi & 3 & $42,9 \%$ & 4 & $57,1 \%$ & & \\
\hline \multicolumn{6}{|l|}{ Tingkat } & \\
\hline $\begin{array}{l}\text { pengetahuar } \\
\text { Tidak Baik }\end{array}$ & 12 & 92,3 & 1 & $7.7 \%$ & \multirow{2}{*}{$\begin{array}{l}9.429 \\
(1.058- \\
84.037)\end{array}$} & \multirow{2}{*}{0,030} \\
\hline Baik & 14 & $56,0 \%$ & 11 & 44,0 & & \\
\hline \multicolumn{7}{|l|}{ Sikap } \\
\hline Negatif & 3 & $15,0 \%$ & 17 & $85,0 \%$ & \multirow{2}{*}{$\begin{array}{l}5,667 \\
(1.219- \\
26.334)\end{array}$} & \multirow[t]{2}{*}{0,049} \\
\hline Positif & 9 & $50,0 \%$ & 9 & $50,0 \%$ & & \\
\hline
\end{tabular}

\section{Pembahasan}

Hasil uji bivariat yang dilakukan menggunakan uji fisher's exact diperoleh nilai $p$ value $0,147(>0,05)$ artinya tidak ada hubungan antara umur dengan perilaku hygiene sanitasi makanan. Hasil ini sesuai dengan hasil temuan di lapangan mendapati adanya pekerja lansia yang memenuhi syarat serta adanya pekerja dewasa yang tidak memenuhi syarat dalam penerapan hygiene sanitasi makanan. Perilaku seseorang umumnya lebih banyak dipengaruhi oleh kebiasaan (Ningsih, 2014). Kebiasaan telah melekat dalam diri seseorang, sehingga jika pekerja terbiasa menerapkan hygiene sanitasi makanan maka tidak menutup kemungkinan baik usia dewasa maupun lansia akan tetap berperilaku demikian.

Meskipun hasil uji statistik tidak memiliki hubungan, akan tetapi masih ada pekerja dewasa yang memenuhi syarat serta ada pula lansia yang memang tidak memenuhi syarat dalam penerapan hygiene sanitasi makanan. Usia berhubungan erat dengan cara berpikir dan bertingkah laku seseorang. Dimana semakin bertambahnya usia akan mempengaruhi cara berpikir seseorang menjadi lebih dewasa karena pengetahuan yang dimiliki semakin meningkat dan luas (Setyawan, 2019). Akan tetapi semakin lanjut usia seseorang maka akan adanya penurunan tingkat kepedulian maupun pemahaman. Karena salah satu faktor kurangnya kepedulian dan pemahaman terhadap hygiene sanitasi makanan dikarenakan usia pralansia seseorang membuat terjadinya penurunan fungsi kognitif dan psikomotorik sehingga perilakum gerakan, dan tindakan seseorang semakin menurun dan lambat (Sutarto \& Cokro, 2013).

Seiring bertambahnnya umur kesadaran seseorang semakin menurun diakibatkan penurunan fungsi kognitif dan psikomotorik seseorang termasuk pada penjamah makanan. Kesadaraan akan penggunaan alat pelindung diri seperti sarung tangan, penutup kepala, dilingkungan kerja sangat kurang sehingga pelatihan dan penyuluhan penting adanya secara bertahap (Prabhusaran $\mathrm{N}$ et al., 2019). Pelatihan dan penyuluhan merupakan salah satu cara untuk meningkatkan pengetahuan penjamah makanan terkait hygiene sanitasi makanan dan penyakit bawaan makanan (foodborne disease) (Webb \& Morancie, 2015). 
Hasil penelitian ini sejalan dengan penelitian terdahulu dengan nilai $\mathrm{p}$ value 0,088 (>0,05) (Widayanti, 2019), sehingga tidak ada hubungan antara usia dengan perilaku hygiene sanitasi makanan. Namun hasil penelitiian ini tidak sejalan dengan penelitian terdahulu dengan nilai $\mathrm{p}$ value $0,009(<0,05)$ (Septiyani et al., 2021).

Hasil analisis dengan uji fisher's exact berikutnya diketahui nilai $\mathrm{p}$ value $0,176(>0,05)$ yang artinya tidak ada hubungan antara tingkat pendidikan dengan perilaku hygiene sanitasi makanan pada pekerja pembuatan kerupuk karak di home industry. Sehingga pendidikan tinggi belum tentu menimbulkan perilaku yang baik. Sebagaimana temuan lapangan, terdapat pekerja yang memiliki pendidikan tinggi namun tidak memenuhi syarat penerapan hygiene sanitasi makanan. Pelatihanlah yang sejatinya akan membangun sebuah perilaku bernilai positif dari hasil peningkatan pengetahuan melaui adanya pemberian materi serta praktek dalam pelatihan (Wagustina, 2013).

Pada hasil penelitian ditemukan pekerja yang memiliki pendidikan rendah namun memenuhi syarat dalam penerapan hygiene sanitasi makanan. Ada kemungkinan pekerja terpengaruh informasi yang bisa didapat melalui media sosial seperti televisi, handphone, ataupun media lainnya mengingat semakin berkembangnya sistem informasi di kalangan masyarakat. Keuntungan yang didapat ataupun diperoleh dengan semakin berkembangnya teknologi di jaman sekarang sebagai sarana informasi yang mudah didapat termasuk tentang pengetahuan hygiene sanitasi makanan salah satunya yaitu handphone, televisi dan lain-lain (Marbun et al., 2020). Sebagaimanapun dalam teori pendidikan, menjelaskan bahwa pendidikan merupakan proses yang dapat mengubah dan membentuk suatu perilaku sesuai dengan tujuan yang diinginkan dari hasil peningkatkan pengetahuan, keterampilan dan sikap (Toenlioe, 2016).

Temuan lainnya yaitu adanya pekerja yang memiliki tingkat pendidikan rendah dan dalam penerapan hygiene sanitasi makanan tidak memenuhi syarat. Sebagaimana hasil observasi, beberapa pekerja tidak dapat membaca dan menulis, sehingga tidak dapat menerima informasi dan menerapkannya dengan baik. Pendidikan memiliki pengaruh terhadap tingkat pengetahuan yang diperoleh. kurangnya pengetahuan mengenai kebiasaan hidup tidak bersih dan pencemaran makanan dapat terjadi secara langsung diakibatkan memegang makanan setelah memegang alat ataupun benda lainnya dari lingkungan kerja dikarenakan kebiasaan sehari-hari sehingga dianggap lumrah (Anwar et al., 2020). Hasil penelitian ini sejalan dengan penelitian terdahulu yang memperoleh temuan bahwa tidak ada hubungan antara tingkat pendidikan dengan hygiene sanitasi makanan dengan nilai $\mathrm{p}$ value 0,695 (>0,05) (Fithri, 2016) dan penelitian lainnya dengan nilai p value 0,126 $(>0,05)$ (Nurfikrizd \& Rustiawan, 2019). Namun, terdapat hasil penelitian lain yang tidak sejalan dengan nilai $\mathrm{p}$ value 0,032 $(<0,05)$ (Handayani et al., 2015).

Hasil uji Fisher's exact diketahui $\mathrm{p}$ value $0,030(0,05)$ yang artinya ada hubungan yang signifikan antara tingkat pengetahuan dengan perilaku hygiene sanitasi makanan. Pengetahuan dapat membentuk suatu perilaku seseorang, sesuai dengan teori Lawrence Green yaitu perilaku seseorang dapat dibentuk oleh tiga faktor, salah satunya faktor predisposisi dalam bentuk pengetahuan, sikap, kepercayaan dan lain-lainnya. 


\begin{abstract}
Sebagaimana temuan dilapangan bahwa terdapat pekerja memiliki pengetahuan baik, diikuti dengan penerapan hygiene sanitasi yang memenuhi syarat. Penjamah makanan yang menerapkan personal hygiene yang baik maupun buruk memiliki risiko besar terhadap makanan yang diolah. Karena pengetahuan yang baik dapat meningkatkan Kesehatan yang baik pula begitu juga sebaliknya (Wani et al., 2019). Sebaliknya ditemukan juga pekerja yang memiliki pengetahuan tidak baik dan penerapan hygiene sanitasi yang tidak memenuhi syarat berdasarkan temuan lapangan hal ini dikarenakan terdapat pekerja yang tidak dapat membaca tulis sehingga mendukung perilaku hygiene sanitasi yang tidak baik.
\end{abstract}

Meskipun hasil statistik penelitian menunjukkan adanya hubungan, namun tidak menutup kemungkinan pengetahuan yang baik tentang hygiene sanitasi makanan belum tentu selaras dengan perilaku yang baik pula dalam penerapannya. Selain pengetahuan, faktor lain yang berpengaruh dalam berperilaku seseorang akibat yaitu kebiasaan penjamah yang belum memperhatikan hygiene sanitasi dalam mengolah makanan (Anwar et al., 2020). Pengetahuan pekerja terhadap pemahaman bahwa makanan yang kurang dapat menyebabkan kontaminasi silang pada saat pengolahan makanan dapat terjadi saat tidak menggunakan sarung tangan ataupun terluka dan bahaya penggunaan bahan tambahan makanan secara berlebihan. Hal ini disebabkan karena penjamah yang tidak memperhatikan kebersihan dan menganggap hal itu tidak berpengaruh terhadap kebersihan makanan (Cempaka et al., 2019). Hasil penelitian sejalan dengan penelitian terdahulu dengan nilai $\mathrm{p}$ value $0,000 \quad(<0,05)$ (Sary et al., 2020), dan penelitian yang dengan nilai $\mathrm{p}$ value 0,032 $(<0,05)$ (Mulyani, 2014), sehingga ada hubungan antara tingkat pengetahuan dengan perilaku hygiene sanitasi makanan.

Hasil uji chi square yang dilakukan didapatkan nilai $p$ value $0,049(<0,05)$ yang artinya terdapat hubungan yang signifikan antara sikap dengan perilaku hygiene sanitasi makanan. Teori bahwa sikap berhubungan dengan perilaku dalam Theory of Reasoned Action (TRA) dan Theory of Planned Behavior (TPB) yang menjelaskan salah satu faktor terbentuknya perilaku dipengaruhi oleh sikap atau kesiapan untuk bertindak termasuk dalam kesehatan (Glanz et al., 2008). Definisi sikap merupakan kumpulan suatu perasaan, keyakinan dan kecenderungan perilaku terhadap gagasan, orang, objek ataupun kelompok tertentu (Rahmayani, 2018). Ketika seseorang memiliki sikap negatif terhadap perilaku hygiene sanitasi makanan seperti menganggap bolehnya tidak memelihara kebersihan lingkungan terutama pada sarana dan fasilitas, sanitasi tempat, dan peralatan maka akan menyebabkan perilaku buruk.

Hasil temuan lapangan yang didapat pertanyaan sikap kebanyakan responden setuju dengan penggunaan masker saat bekerja, mencuci tangan, menggunakan sarung tangan, menggunakan peralatan dalam kondisi yang baik dan rutin memeriksa kesehatannya, tetapi karena keterbatasan fasilitas sehingga tidak diterapkan dengan baik. Fasilitas yang kurang ataupun tidak tersedia seperti masker, sarung tangan dan lain-lain membuat mereka tidak dapat memenuhi persyaratan penerapan hygiene sanitasi makanan dengan baik. Hal lain yang ditemukan dalam temuan lapangan sikap respon tertutup kemungkinan dipengaruhi oleh kondisi emosional seseorang (Mulyani, 2014). Emosional perempuan lebih kuat 
dibandingkan dengan laki-laki (Deng et al., 2016). Perempuan lebih sensitif terhadap sebuah rangsangan termasuk dalam menyikapi. Perbedaan jenis kelamin dalam pengalaman emosional dan ekspresi emosional mungkin bergantung pada emosi tertentu terhadap valensi (negatif, positif, netral). Adapun hasil temuan lapangan dalam penelitian didapatkan bahwa pekerja kebanyakan mayoritas pekerja perempuan dibandingkan laki-laki.

Selain itu juga, kebiasaan mengenai kebersihan diri merupakan sikap yang harus diterapkan dalam mengolah makanan. Kebiasaan pekerja seperti menggosok hidung, menggaruk bagian tubuh, bersin, menguap dan batuk diikuti dengan tidak menggunakan masker merupakan kebiasaan yang dapat mempengaruhi sikap keamanan pangan. Kebiasaan kotor ini berkontribusi terjadinya kontaminasi pada makanan (Abdullahi et al., 2020). Hasil penelitian ini sejalan dengan penelitian terdahulu dengan nilai $p$ value $0,020(<0,05)$ (Julizar, 2014) dan penelitian lainnya mengatakan bahwa ada hubungan yang signifikan antara sikap dengan perilaku hygiene sanitassi makanan (Rahmayani, 2018).

\section{Kesimpulan}

Berdasarkan hasil penelitian yang telah dilakukan terkait faktor-faktor yang mempengaruhi dengan perilaku hygiene sanitasi makanan pada pekerja pembuatan kerupuk karak di home industry Kecamatan Kerjo Kabupaten Karanganyar dapat disimpulkan bahwa: variabel usia dan tingkat pendidikan tidak mempengaruhi perilaku pekerja. Sedangkan tingkat pengetahuan dan sikap pekerja secara statistik sebagai faktor-faktor yang mempengaruhi perilaku.

\section{Referensi}

Abdullahi, B. S., Maiha, S. B., \& Lawal, H. K.
(2020). Hygiene, Food Safety Practices and Sanitation in Some Food Service Centres in Zaria, Kaduna State, Nigeria. American Journal of Food Science and Technology, 8(5), 206-210.

Anwar, K., Navianti, D., \& Rusilah, S. (2020). Perilaku Hygiene Sanitasi Penjamah Makanan Di Rumah Makan Padang Wilayah Kerja Puskesmas Basuki Rahmat Kota Palembang. Jurnal Dunia Kesmas, 9(4), 512-520. https://doi.org/10.33024/jdk.v9i4.33 02

BPOM. (2017). Profil Badan Pengawasan Obat dan Makanan Republik Indonesia Tahun 2017.

BPOM. (2019). Laporan Tahunan Pusat Data dan Informasi Obat dan Makanan Tahun 2019. BPOM RI.

Cempaka, L., Rizki, A. A., \& Asiah, N. (2019). Knowledge, Attitudes and Practices Regarding Food Hygiene and Sanitation of Food Street Handlers in the Public Elementary School at Greater Jakarta, Indonesia. Asia Pacific Journal of Sustainable Agriculture, Food and Energy, $\quad 7(2), \quad$ 1-8. https://doi.org/10.36782/apjsafe.v7i2 .1944

Deng, Y., Chang, L., Yang, M., Huo, M., \& Zhou, R. (2016). Gender differences in emotional response: Inconsistency between experience and expressivity. Plos One, 11(6), 1-12.

Fithri, N. K. (2016). Hygiene dan Sanitasi pada Penjamah Makanan di Kantin Universitas Esa Unggul. Jurnal Inohim, 4(2), 43-48.

Glanz, K., Rimer, B. k., \& Viswanath, K. (2008). Health Behavior And Health Education: Theory, Research, and Practice (4th Ed). Josse Bass.

Handayani, N. M. A., Adhi, K. T., \& Duarsa, D. P. (2015). Faktor yang Mempengaruhi Perilaku Penjamah Makanan dalam Penerapan Cara Pengolahan Pangan yang Baik pada Industri Rumah Tangga Pangan di Kabupaten Karangasem. Public Health and Preventive Medicine Archive, 3(2), 155.

Hatta, M., \& Marahena, A. (2018). Gambaran Hygiene Sanitasi Pengelolaan Makanan Di Reastoran Madura Kota Masohi Kabupaten Maluku Tengah. Jurnal 
Mitrasehat, 8(2).

Julizar, M. (2014). Hubungan Karakteristik Pedagang Makanan Kaki Lima Dengan Hygiene Sanitasi Makanan di Kota Meulaboh Kecamatan Johan Pahlawan Kabupaten Aceh Barat Tahun 2014. Universitas Teuku Umar.

Li, W., Pires, S. M., Liu, Z., Ma, X., Liang, J., Jiang, Y., Chen, J., Liang, J., Wang, S., \& Wang, L. (2020). Surveillance of foodborne disease outbreaks in China, 2003-2017. Food Control, 118, 107359.

Marbun, D. S., Juliandi, A., \& Effendi, S. (2020). The Effect of Social Media Culture and Knowledge Transfer on Performance. Budapest International Research and Critics Institute (BIRCIJournal): Humanities and Social Sciences, 3(3), 2513-2520. https://doi.org/10.33258/birci.v3i3.1 234

Marriott, N. G., Schilling, M. W., \& Gravani, R. B. (2018). Principles of food sanitation. Springer.

Mulyani, R. (2014). Pengetahuan, Sikap dan Perilaku Higiene Pengolah Makanan. $X(1), 6-12$.

Ningsih, R. (2014). Penyuluhan Hygiene Sanitasi Makanan Dan Minuman, Serta Kualitas Makanan Yang Dijajakan Pedagang Di Lingkungan Sdn Kota Samarinda. Jurnal Kesehatan Masyarakat, 10(1), 64-72.

Notoatmodjo, S. (2011). Kesehatan Masyarakat (pp. 109-111 dan 135146). Rineka Cipta.

Nurfikrizd, A., \& Rustiawan, A. (2019). Hubungan Karakteristik Individu dengan Perilaku Keamanan Pangan pada Penjamah Makanan di Rumah Makan Kawasan Wisata Kuliner Pantai Depok Kabupaten Bantul. Naskah Publikasi Universitas Ahmad Dahlan, 113.

Pires, S. M., \& Devleesschauwer, B. (2021). Estimates of global disease burden associated with foodborne pathogens. In Foodborne Infections and Intoxications (pp. 3-17). Elsevier.

Prabhusaran N, Manivannan L, Pramila M, \& Prabhakar Y.K. (2019). Knowledge , Attitude and Practice of Personal Hygiene , Cleaning And Sanitation During Food Processing. European
Jurnal of Pharmaceutical and Medical Research, 5(June 2018), 455-461.

Rahmayani. (2018). Hubungan pengetahuan, sikap dan tindakan hygiene sanitasi pedagang makanan jajanan di pinggir jalan. AcTion: Aceh Nutrition Journal, 3(2), 172. https://doi.org/10.30867/action.v3i2. 84

Sary, A. N., Harmawati, \& Azmir, B. (2020). Hubungan Tingkat Pengetahuan Dan Sikap Keamanan Pangan Dengan Tindakan Hygiene Penjaja Makanan Jajanan Anak Sekolah Dasar. Jurnal Endurance: Kajian Ilmiah Problema Kesehatan, 5(3), 550-556.

Septiyani, D., Suryani, D., \& Yulianto, A. (2021). Hubungan Pengetahuan, Sikap, Tingkat Pendidikan dan Usia dengan Perilaku Keamanan Pangan Ibu Rumah Tangga di Kecamatan Pasaleman, Cirebon. Journal of Public Health, 4(1), 45-54.

Setyawan, F. E. B. (2019). Pendekatan Pelayanan Kesehatan Dokter Keluarga (Pendekatan Holistik Komprehensif). Zifatama Jawara.

Siyam, N., \& Cahyati, W. H. (2018). Peningkatan Kapasitas Penghuni Pondok Pesantren dalam Pencegahan Food Borne Disease dengan Metode Peer Education. VISIKES: Jurnal Kesehatan Masyarakat, 17(02).

Supitra, I., Simanjuntak, R. A., \& Yusuf, M. (2018). Perancangan Fasilitas Kerja Pembuatan Emping Melinjo Untuk Mengurangi Keluhan Dengan Standar Nordic Questionnair (SNQ)(Studi Kasus Pada Home Industry Desa Murangan Yogyakarta). Jurnal Rekavasi, 6(1), 1-6.

Sutarto, J. T., \& Cokro, C. I. (2013). Pensiun Bukan Akhir Segalanya. PT Gramedia Pustaka Utama.

Todd, E. (2020). Food-borne disease prevention and risk assessment. In International Journal of Environmental Research and Public Health (Vol. 17, Issue 14, p. 5129). Multidisciplinary Digital Publishing Institute.

Toenlioe, J. S. (2016). Teori dan Filsafat Pendidikan. Gunung Samudera.

Wagustina, S. (2013). Pengaruh Pelatihan Hygiene dan Sanitasi terhadap Pengetahuan dan Perilaku Penjamah 
Makanan di Instalasi Gizi Rumah Sakit Umum Daerah Meuraxa Banda Aceh. Jurnal Ilmiah STIKes U'Budiyah, 2(1), 66-77.

Wani, Y. A., Tanuwijaya, L. K., \& Arfiani, E. P. (2019). Manajemen Operasional Penyelenggaraan Makanan Massal (pp. 37-45). UB Press.

Webb, M., \& Morancie, A. (2015). Food Safety Knowledge of Foodservice Workers At a Universitity Campus by Education Level, Experience, and Food Safety Training. Journal of Food Control, 50, 259-264.

Widayanti, Y. T. (2019). Hubungan Antara Pengetahuan dan Perilaku Terkait Keamanan Pangan Pada Wanita yang Bekerja Di Universitas Muhammadiyah Surakarta. Universitas Muhammadiyah Surakarta. 